\title{
Effect of frozen storage and cooking method on amino acid composition of mullet fish (Mugil cephalus)
}

\begin{abstract}
The current study was carried out to investigate the effect of frying and grilling cooking methods on amino acid composition of Mullet fish (Mugil cephalus) obtained from Wadi EI-Ryan Lake, at Fayoum, Egypt. The study also included the effects of frozen storage of raw Mullet fish steaks for 6 months on amino acid profile. Fresh Mullet had good protein quality as indicated by high of total amino acids (TAA), total essential amino acids (EAA) and Amino acid score (AAS). These quality indicators were slightly decreased after 180 days of frozen storage. Fried and grilled products have a high nutritional quality of protein and high nutritional value as indicated by high values of (TEAA), Amino acid score (AAS) and percentage satisfaction (P.S\%/150) of essential amino acids upon consuming $150 \mathrm{~g}$ of the products and the grams consumed to cover the daily requirements of essential amino acids for adult man were lower.
\end{abstract}

Keywords: mullet fish, amino acid, frozen storage, frying, grilling
Volume 6 Issue 6 - 2018

\author{
El Lahamy AA,' Khalil KI, ${ }^{2}$ El Sherif SA,' \\ Abdelazim SAA, ${ }^{3}$ Mahmud $\mathrm{AA}^{2}$ \\ 'National Institute of Oceanography and Fisheries, Fish \\ Processing Technology Laboratory, Egypt \\ ${ }^{2}$ Food Science and Technology Department, Egypt \\ ${ }^{3}$ Food Technology Research Institute, Agricultural Research \\ Center, Egypt
}

Correspondence: El Lahamy AA, National Institute of Oceanography and Fisheries, Fish Processing Technology Laboratory, Cairo, Egypt, Email adelammar I I@yahoo.com

Received: November 10, 2018 | Published: November 16, 2018

\section{Introduction}

Fish and fishery products have long been recognized as healthy foods with excellent nutritional value, providing high-quality protein, minerals, vitamins, essential fatty acids and trace elements. Fish is widely consumed in many parts of the world by humans due to its high content of good protein that characterizes by an excellent amino acid composition and easily digestibility. ${ }^{1}$ Fish proteins are easily digestible and contain significant amounts of all the essential aminoacids, principally lysine and the sulphur-containing amino-acids (methionine and cysteine) that are often present in low quantities in vegetables, cereals and legumes. Fish protein can therefore be used to complement the amino acid pattern and the overall protein quality in human diet. ${ }^{2,3}$

Fish is usually cooked in different methods such as boiling, smoking, roasting, frying and grilling. These processing and cooking methods improve the hygienic quality by inactivation of pathogenic microorganisms and enhance the digestibility and bio-availability of nutrient in the digestive tract. ${ }^{4}$ Freezing is a much preferred technique to preserve fish and fish products for long period of time. It permits to preserve the flavor and the nutritional properties of foods better than storage above the initial freezing temperature. It also has the advantage of minimizing microbial or enzymatic activity. ${ }^{5}$ Freezing requires lowering the temperature to $-18^{\circ} \mathrm{C}$ or lower and is a popular method of preserving fish. ${ }^{6}$ Frozen storage has been widely employed to retain fish properties before it is consumed or employed in other technological processes. Thermal processing techniques are widely used to improve eating quality and safety of food products and to extend the shelf life of the products. Fish and fishery products are cooked in different ways to improve its hygienic quality by inactivation of pathogenic microorganisms and to enhance its flavor and taste. ${ }^{7}$ During cooking, some chemical and physical reactions take place which either improve or impair the food nutritional value. Therefore, digestibility is increased because of protein denaturation in food while, the content of thermo labile compounds, fat-soluble vitamins or polyunsaturated fatty acids is often reduced.

\section{Material and methods}

\section{Mullet fish (Mugil cephalus)}

Fresh Mullet fish (Mugil cephalous) was obtained from Wadi ElRayan Lake during February 2016. Averages of weight and length ranged between $1.3-1.5 \mathrm{~kg}$ and $46-52 \mathrm{~cm}$, respectively. Mullet fish samples were kept in an

ice-box and transported to the laboratory of Fish Processing Technology, Shakshouk Station for Fish Research, National Institute of Oceanography and Fisheries, Fayoum Governorate, Egypt. The fish samples were beheaded, gutted and cut into steaks then washed gently with tap water. The prepared raw fish steaks samples were divided into two groups and packed in polyethylene bags then stored at $-18^{\circ} \mathrm{C}$ for 6.0 months. At intervals of 6.0 months, samples of frozen fish fillets were withdrew, thawed and cooked with two methods; frying and grilling.

\section{Cooking methods}

Frying and grilling cooking methods were carried out on the prefrozen Mullet fish steaks at zero time of storage and at 6.0 months.

\section{Frying}

Frozen Mullet steaks were thawed, soaked in saturated salt solution for two minutes, and then spices mixture was put in the steaks cavity and rubbed with flour. The steaks were fried in sunflower oil heated at $180^{\circ} \mathrm{C}$ for 5 minutes for each side of the steaks using electrical fryer pan Moulinex and then the fried steaks were drained in basket to remove excess oil. 


\section{Grilling}

Frozen Mullet steaks were thawed, rubbed with bran and grilled using electrical grill machine at $260^{\circ} \mathrm{C}$ for 15 minutes for each side of the steaks. The grilled fish samples were spiced for 1 minute using a special spiced solution containing black pepper, cumin, red pepper and garlic.

\section{Analytical method}

\section{Amino acids analysis}

Amino acids determination: Amino acid contents were determined by using HPLC and Amino acid analyzer LC3000 Eppendr of Germany at National Research Center according to the method described by Andrew. ${ }^{9}$ Tryptophan was not determined.

Amino acid score (A.A.S.): Amino acid score was calculated for the essential amino acids ( $\mathrm{g} / 100 \mathrm{~g}$ protein) using Standard ${ }^{10}$ according to Bhanu ${ }^{11}$ using the following equation:

$$
\text { A.A.S. }=\frac{\text { E. A. A. in tested sample }(\mathrm{g} / 100 \mathrm{~g} \text { protein })}{\text { E. A. A. of reference protein }(\mathrm{g} / 100 \mathrm{~g} \text { protein })} \times 100
$$

A.A.S. value less than 100 indicated the deficiency in the considered amino acid. The acid which showed highest deficiency (lowest A.A.S.) was called the limited amino acid (L.A.A.).

Daily Requirements (G.D.R.) and the Percentage Satisfaction (P.S.\%/150g): Gram daily requirements (g) of products were illustrated by essential amino acids composition ( $\mathrm{g} / 100 \mathrm{~g}$ sample) which should be consumed to cover the daily requirements for adult man (recommended daily dietary allowances).

Daily requirements (G.D.R.) were calculated using the following equation:

$$
\text { G.D.R. }=\frac{\text { Reference pattern }(\text { USRDA, 1989 })(100 \mathrm{~g} \text { sample })}{\text { gAA } / 100 \mathrm{~g} \text { product }}
$$

Percentages of satisfaction (P.S. \%) of the daily requirements for adult man in the essential amino acid when consuming $150 \mathrm{~g}$ of mullet fish products (P.S.\%/150g) were calculated using the recommended daily dietary allowances given by USRDA. ${ }^{12}$

The percentages of satisfaction (P.S.\%/150g) were calculated using the following equation:

$$
\text { P.S. } \% / 150 \mathrm{~g}=\frac{150 \mathrm{~g} \times 100}{\text { G.D.R., } g}
$$

\section{Effect of frozen storage and cooking methods on amino acid of mullet fish}

\section{Amino acid composition of mullet}

Effects of frozen storage at $-18^{\circ} \mathrm{C}$ of raw Mullet fish and cooking method on the nutritional value of raw and cooked products were investigated based on their contents of amino acids.
Amino acid profiles of the raw Mullet fish sample were determined at zero time and after 180 days of frozen storage and data obtained are presented in Table 1. The results showed the high quality of Mullet fish protein as it was indicated from its high contents (fresh sample) of the different amino acids including the essential and non-essential amino acids. Expect the amino acid tryptophan, all the essential amino acids were found in Mullet fish. The essential amino acids amounted by $41.54 \mathrm{~g} / 100 \mathrm{~g}$ protein which represent more than $47.0 \%$ of the total amino acids found in Mullet fish. Glutamic acid was found to be the predominate amino acid with concentration of $11.07 \mathrm{~g} / 100 \mathrm{~g}$ protein followed by aspartic acid with concentration of $9.02 \mathrm{~g} / 100 \mathrm{~g}$ protein. Leucine, Lysine, arginine, isoleucine, valine, phenylalanine, threonine and serine were determined by $6.98,6.62,5.15,4.83,4.48,4.35,4.53$ and $4.17 \mathrm{~g} / 100 \mathrm{~g}$ protein, respectively. The other amino acids were also found with considerable concentrations. Similar results were found by Shady. ${ }^{13}$ who mentioned that glutamic acid was the abundant amino acid followed by aspartic acid of the total amino acids determined in several species of fish.

Table I Effect of frozen storage on amino acid composition of Mullet fish steaks

\begin{tabular}{lll}
\hline & \multicolumn{2}{c}{ g AA / O0g protein in Mullet fish steaks } \\
\cline { 2 - 3 } Amino acid (AA) & Fresh(Un frozen) & $\begin{array}{l}\text { Frozen } \\
\text { stored(6.0 } \\
\text { months) }\end{array}$ \\
\hline Essential Amino Acids & (EAA)* & \\
Isoleucine & 4.83 & 4.76 \\
Leucine & 6.98 & 6.7 \\
Threonine & 4.53 & 4.34 \\
Valine & 4.48 & 4.3 \\
Phenylalanine & 4.35 & 4.1 \\
Tyrosine & 2.95 & 3.05 \\
Methionine & 2.85 & 2.8 \\
Cystine & 1.1 & 0.95 \\
Tryptophan & ND & ND \\
Lysine & 6.62 & 6.6 \\
Histidine** & 2.85 & 2.75 \\
Non Essential Amino Acids (NEAA) & \\
Serine & 4.17 & 4.52 \\
Glycine & 5.02 & 4.6 \\
Alanine & 5.85 & 5.61 \\
Proline & 4.9 & 4.55 \\
Aspartic & 9.02 & 8.58 \\
Glutamic & 11.07 & 10.75 \\
Argnine & 5.15 & 5.2 \\
TEAA & 41.54 & 40.35 \\
TNEAA & 45.18 & 83.81 \\
TAA & 86.72 & \\
\hline & & \\
\hline
\end{tabular}




\section{Effect of frozen storage on amino acid composition of mullet fish steaks}

The results presented in Table 1 show the effect of frozen storage for 6.0 months at $-18^{\circ} \mathrm{C}$ on amino acid composition of Mullet fish. Frozen storage showed no considerable changes on amino acids contents of Mullet fish. Cystine showed the highest loss that determined by about $13.0 \%$, while tyrosine, serine and argnine slightly increased. Data showed that after 6.0 months of frozen storage, the essential, nonessential and total amino acids were determined by $40.35,43.81$ and $84.16 \mathrm{~g} / 100 \mathrm{~g}$ protein, respectively which represented more than 97.0 $\%$ of their concentrations in the raw samples before storage. Similar results were found by Wesselinova. ${ }^{14}$ who showed that frozen storage at $-35^{\circ} \mathrm{C}$ did not influence dramatically on the amino acid values of the examined fish species. He reported that the highest loss of amino acids during frozen storage was determined by $13 \%$ for cysteine. Also, Castrillon ${ }^{15}$ reported that the amino acid that was most damaged during the process of freezing storage and defrosting was cysteine. The increases observed in some amino acids during frozen storage could be due to transition of one kind of amino acid to another through oxidation, deamination, etc. ${ }^{14}$

\section{Effect of cooking methods on amino acid composition of mullet fish steaks}

The effect of cooking methods (frying and grilling) on amino acids compositions of the Mullet fish steaks was determined. Amino acids were determined in fresh Mullet fish and its fried and grilled products before storage. After 6.0 months of frozen storage of Mullet fish, samples of Mullet fish steaks were fried and grilled and amino acids were determined in the frozen stored fish sample and the fried and grilled samples prepared from the pre frozen stored fish steaks. Data obtained are presented in Table 2 and Table 3. It was found that several amino acids showed slight decreases due to frying and grilling processes while some others slightly increased either in the cooked samples from fresh fish steaks (Table 2) or from the frozen stored (for 6.0 months) steaks (Table 3). The results showed that in the fried steaks made from fresh Mullet fish sample (Table 2), the sulphur containing amino acids Cystine showed the highest loss which was accounted by $51.81 \%$ and methionine decreased by $20.35 \%$. Also, the amino acids; serine, threonine, lysine, phenylalanine and tyrosine decreased by $22.54,17.21,11.63 \%, 9.19$ and $8.81 \%$ respectively. On the other hand, the results recorded in Table 2 showed slight increases in fried Mullet fish contents of some amino acid such as histidine, glycine and alanine. The same trends were also found in the amino acid composition of the grilled Mullet sample. The results (Table 2) showed that the loss was particularly more observed in the sulphur containing amino acids cystine and methionine that determined by 23.63 and $22.45 \%$, respectively.

Table 2 Effect of cooking methods on amino acid composition of fresh Mullet fish steaks

\begin{tabular}{|c|c|c|c|}
\hline \multirow[b]{2}{*}{ Amino acid (AA) } & \multicolumn{3}{|c|}{ g AA/ $100 \mathrm{~g}$ protein in Mullet fish steaks } \\
\hline & $\begin{array}{l}\text { Fresh } \\
\text { steaks }\end{array}$ & $\begin{array}{l}\text { Fried } \\
\text { steaks }\end{array}$ & $\begin{array}{l}\text { Grilled } \\
\text { steaks }\end{array}$ \\
\hline \multicolumn{4}{|c|}{ Essential Amino Acids (EAA)* } \\
\hline Isoleucine & 4.83 & 4.1 & 4.33 \\
\hline Leucine & 6.98 & 6.65 & 7.35 \\
\hline Threonine & 4.53 & 3.75 & 4.18 \\
\hline Valine & 4.48 & 3.9 & 4.25 \\
\hline
\end{tabular}

$\begin{array}{llll}\text { Phenylalanine } & 4.35 & 3.95 & 4.25 \\ \text { Tyrosine } & 2.95 & 2.69 & 3.49 \\ \text { Methionine } & 2.85 & 2.27 & 2.21 \\ \text { Cystine } & 1.1 & 0.53 & 0.84 \\ \text { Tryptophan } & \mathrm{ND} & \mathrm{ND} & \mathrm{ND} \\ \text { Lysine } & 6.62 & 5.85 & 6.22 \\ \text { Histidine** } & 2.85 & 3.05 & 2.5 \\ \text { Non Essential Amino } & \text { Acids (NEAA) } & & \\ \text { Serine } & 4.17 & 3.23 & 3.98 \\ \text { Glycine } & 5.02 & 5.29 & 5.12 \\ \text { Alanine } & 5.85 & 5.97 & 6.17 \\ \text { Proline } & 4.9 & 4.48 & 4.72 \\ \text { Aspartic } & 9.02 & 8.8 & 9.05 \\ \text { Glutamic } & 11.07 & 10.9 & 11.02 \\ \text { Argnine } & 5.15 & 4.87 & 5.19 \\ \text { EAA } & 41.54 & 36.74 & 39.62 \\ \text { NEAA } & 45.18 & 43.54 & 45.25 \\ \text { TAA } & 86.72 & 80.28 & 84.87 \\ \text { Ess } & & & \end{array}$

*Essential amino acids according to FAO.21

**Indispensable amino acid in human adult according to FAO. ${ }^{22}$ ND, not determined

Table 3 Effect of cooking methods on amino acid composition of pre frozen Mullet fish steaks (stored for 6.0 months

\begin{tabular}{|c|c|c|c|}
\hline \multirow[b]{2}{*}{$\begin{array}{l}\text { Amino acid } \\
\text { (AA) }\end{array}$} & \multicolumn{3}{|c|}{ gAA/ $100 \mathrm{~g}$ protein in Mullet fish steaks } \\
\hline & $\begin{array}{l}\text { Frozen stored } \\
\text { (6.0 months) }\end{array}$ & $\begin{array}{l}\text { Fried steaks } \\
\text { from frozen } \\
\text { stored (6.0 } \\
\text { months) }\end{array}$ & $\begin{array}{l}\text { Grilled steaks } \\
\text { from frozen } \\
\text { stored ( } 6.0 \\
\text { months) }\end{array}$ \\
\hline \multicolumn{4}{|c|}{ Essential Amino Acids (EAA)* } \\
\hline Isoleucine & 4.76 & 3.95 & 4.3 \\
\hline Leucine & 6.7 & 6.45 & 7.15 \\
\hline Threonine & 4.34 & 3.6 & 3.9 \\
\hline Valine & 4.3 & 3.72 & 4 \\
\hline Phenylalanine & 4.1 & 3.75 & 4.12 \\
\hline Tyrosine & 3.05 & 2.5 & 3.25 \\
\hline Methionine & 2.8 & 2.15 & 2.05 \\
\hline Cystine & 0.95 & 0.5 & 0.65 \\
\hline Tryptophan & ND & ND & ND \\
\hline Lysine & 6.6 & 5.6 & 6 \\
\hline Histidine** & 2.75 & 2.94 & 2.35 \\
\hline \multicolumn{4}{|c|}{ Non Essential Amino Acids (NEAA) } \\
\hline Serine & 4.52 & 3.1 & 3.75 \\
\hline Glycine & 4.6 & 5.05 & 5.1 \\
\hline Alanine & 5.61 & 5.8 & 6 \\
\hline Proline & 4.55 & 4.32 & 4.45 \\
\hline Aspartic & 8.58 & 8.48 & 8.7 \\
\hline
\end{tabular}


Table Continued

\begin{tabular}{llll}
\hline \multirow{2}{*}{$\begin{array}{l}\text { Amino acid } \\
\text { (AA) }\end{array}$} & $\begin{array}{l}\text { F AA/ } \mathbf{0 0 g} \text { protein in Mullet fish steaks } \\
\text { (6.0 months) }\end{array}$ & $\begin{array}{l}\text { Fried steaks } \\
\text { from frozen } \\
\text { stored }(6.0 \\
\text { months) }\end{array}$ & $\begin{array}{l}\text { Grilled steaks } \\
\text { from frozen } \\
\text { stored }(6.0 \\
\text { months) }\end{array}$ \\
\hline Glutamic & 10.75 & 10.5 & 10.65 \\
Argnine & 5.2 & 4.68 & 5.1 \\
EAA & 40.35 & 35.16 & 37.77 \\
TNEAA & 43.81 & 41.93 & 43.75 \\
TAA & 84.16 & 77.09 & 81.52
\end{tabular}

*Essential amino acids according to $\mathrm{FAO}^{2}$

**Indispensable amino acid in human adult according to FAO. ${ }^{22}$

ND, not determined.

The results shown in Table 2 indicated that the essential amino acids contents of fresh, fried and grilled Mullet fish steaks were 41.54 36.74 and $39.62 \mathrm{~g} / 100 \mathrm{~g}$ protein, respectively while their contents of the non- essential amino acids were $45.18,43.53$ and $45.25 \mathrm{~g} / 100 \mathrm{~g}$ protein, respectively and the total amino acids contents were 86.72 , 80.28 and $84.87 \mathrm{~g} / 100 \mathrm{~g}$ protein, respectively. These data show that frying process resulted more loss in amino acids in comparison to the effect of grilling process.

Data given in Table 3 show amino acids contents of the pre frozen and stored (6.0 months) Mullet fish steaks and the fried and grilled samples prepared from the frozen stored samples. The trends found in amino acid compositions of the fried and grilled samples obtained from the fresh Mullet fish steaks were also observed in the fried and grilled products obtained from the frozen stored for 6.0 months sample. In the fried samples, the loss was particularly more observed in serine and threonine which decreased by $31.41 \%$ and $17.05 \%$, respectively. Isoleucine lysine, and valine also showed a noticed decreases estimated by $17.01 \%, 15.15 \%$ and $13.48 \%$, respectively. Sulphur containing amino acid; Cystine and methionine showed a reduction accounted by $47.36 \%$ and $23.21 \%$, respectively while the losses observed in tyrosine and phenylalanine were determined by $18.03 \%$ and $8.53 \%$ respectively. On the other hand, results recorded in Table 3 showed slight increases in fried Mullet contents of some amino acids such as histidine, glycine and alanine. Tryptophan was not determined in all Mullet fish samples.

In the grilled Mullet sample, the loss was particularly more observed in sulphur containing amino acid; cystine and methionine that showed a reductions accounted by $26.78 \%$ and $31.57 \%$, respectively while the decreasing observed in serine, histidine and threonine were determined by $17.03 \%, 14.54$ and $10.13 \%$, respectively. On the other hand results recorded in Table 3 showed slight increases in grilled Mullet fish sample contents of some amino acid such as tyrosine, leucine, phenylalanine, aspartic, glycine and alanine.

Data presented in Table 3 showed that the essential amino acids contents of the 6.0 months frozen stored Mullet fish steaks and their fried and grilled products were $40.35,35.16$ and $37.77 \mathrm{~g} / 100 \mathrm{~g}$ protein, respectively while their contents of the non essential amino acids were $43.81,41.93$ and $43.75 \mathrm{~g} / 100 \mathrm{~g}$ protein, respectively and the total amino acids were $84.16,77.09$ and $81.52 \mathrm{~g} / 100 \mathrm{~g}$ protein, respectively. The general trend that could be observed was frying process resulted in more losses in amino acids comparing with the grilling process.

Similar results were reported by Oluwaniyi ${ }^{16}$ who found that frying fish with palm oil appeared to have the worst effect on the amino acid composition resulting in the loss of essential amino acids of Catfish (Clariasgariepinus) and Tilapia (Oreochromisniloticus). Previous workers have reported varying effects of processing on the protein and amino acid contents of fish. Some investigators reported no significant effect on protein and amino acid contents following boiling and frying of fish, ${ }^{17}$ while others reported that heat processing resulted in reduction in protein content by destroying some amino acids or making them unavailable. . $^{16,18,19}$

The changes found in amino acids of the fried and grilled Mullet fish samples may be attributed to the influence of heat during cooking operations. These observations could be due to some reactions such as deamination, decarboxylation and oxidation of amino acids which are known to be occurred during heat processing of protein containing food products. ${ }^{20}$

\section{Amino Acid Score (AAS)}

To assess the quality of protein contents of the fried and grilled Mullet fish steaks, amino acid scores (AAS) of the essential amino acid were calculated and data obtained are presented in Table 4 and Table 5.

Table 4 Amino acid scores (AAS) of fried and grilled Mullet fish steaks made from fresh sample

\begin{tabular}{lllll}
\hline \multirow{2}{*}{$\begin{array}{llll}\text { Essential } \\
\text { Amino acid }\end{array}$} & $\begin{array}{l}\text { Standard } \\
\text { FAO/WHO } \\
\text { (199I) }(\mathbf{g} / 100\end{array}$ & \multicolumn{3}{l}{ Amino acid scores $(\%)$} \\
\cline { 5 - 5 } & g protein) & Fresh & Fried & Grilled \\
steaks & steaks & steaks \\
\hline Ile & 2.8 & 173 & 146 & 155 \\
Leu & 6.6 & 105 & 101 & 111 \\
Lys & 5.8 & 114 & 101 & 107 \\
Met+Cys & 2.5 & 158 & 112 & 122 \\
Phe+Tyr & 6.3 & 116 & 105 & 123 \\
Thr & 3.4 & 142 & 110 & 123 \\
Try & 1.1 & $\mathrm{ND}$ & $\mathrm{ND}$ & $\mathrm{ND}$ \\
Val & 3.5 & 128 & 111 & 121 \\
His & 1.9 & 150 & 161 & 132 \\
\hline
\end{tabular}

Table 5 Amino acid scores (AAS) of fried and grilled Mullet fish steaks made from frozen stored sample

\begin{tabular}{|c|c|c|c|c|}
\hline \multirow{2}{*}{$\begin{array}{l}\text { Essential } \\
\text { Amino } \\
\text { acid }\end{array}$} & \multirow{2}{*}{$\begin{array}{l}\text { Standard FAOI } \\
\text { WHO (I99I) } \\
\text { (g/l00 g protein) }\end{array}$} & \multicolumn{3}{|c|}{ Amino acid scores (\%) } \\
\hline & & $\begin{array}{l}\text { Frozen } \\
\text { steaks }\end{array}$ & $\begin{array}{l}\text { Fried } \\
\text { steaks }\end{array}$ & $\begin{array}{l}\text { Grilled } \\
\text { steaks }\end{array}$ \\
\hline Ile & 2.8 & 170 & $|4|$ & 153 \\
\hline Leu & 6.6 & 101 & 97 & 108 \\
\hline Lys & 5.8 & 113 & 96 & 103 \\
\hline Met+Cys & 2.5 & 150 & 106 & 108 \\
\hline Phe+Tyr & 6.3 & 113 & 99 & 116 \\
\hline Thr & 3.4 & 127 & 105 & 114 \\
\hline Try & I.I & ND & ND & ND \\
\hline Val & 3.5 & 122 & 106 & 114 \\
\hline His & 1.9 & 144 & 154 & 123 \\
\hline
\end{tabular}

The results indicated the high nutritive value of Mullet protein which is confirmed from the higher values of amino acid scores for the different essential amino acid in relation to the standard protein 
reference. ${ }^{10}$ Amino acid scores for the different essential amino acid available in raw (uncooked) Mullet fish steaks ranged between 105 for leucine to 173 for isoleucine.

Moreover, changes occurred in amino acid composition due to cooking process showed no considerable changes on the levels of the different essential amino acids. Amino acid scores for the essential amino acids of grilled Mullet steaks made from fresh steaks were found to be higher than the fried samples. The results (Table 4) indicated that amino acid scores for the essential amino acids ranged between the lowest value of $101 \%$ for leucine in fried sample to the highest value of $155 \%$ for isoleucine in the grilled sample. The high values of amino acid scores for the essential amino acids available in the grilled and fried Mullet samples indicated the high quality of Mullet protein of the cooked Mullet samples.

The results (Table 5) indicated that amino acid scores for the essential amino acids in Mullet fish sample stored for 6.0 months at $-18^{\circ} \mathrm{C}$ showed high values in the range of $101 \%$ for leucine to $170 \%$ for isoleucine. In the same trend, amino acid scores for the essential amino acids in the cooked Mullet fish steaks made from pre frozen stored steaks (6.0 months) showed values ranged between the lowest value of $96 \%$ for lysine in fried sample to the highest value of $153 \%$ for isoleucine in grilled sample. Amino acid score (AS) for the essential amino acids (EAA) of fried and grilled Mullet fish sample made from steaks before storage were found to be higher than 100 indicating no deficiency in any essential amino acids due to cooking method as compared with FAO references protein. while, (AS) of the same product after 6.0 months storage were less than 100 for leucine (97\%), lysine (96\%) and Phenylalanine+Tyrosine (99\%) in fried Mullet samples. ${ }^{21,22}$

Estimating the Gram Daily Requirements (GDR) and the Percentage of Satisfaction (PS \%/150): The quantities consumed of the fried and grilled Mullet fish steaks to cover the daily requirements of adult $(\mathrm{GDR}, \mathrm{g})$ and the percentages of satisfaction of these requirements by consuming $150 \mathrm{~g}(\mathrm{PS} \% 150 \%)$ in relation to USRDA ${ }^{12}$ were calculated and data obtained are presented in Table 6 and Table 7 .

Table 6 Daily requirements (GDR) and the percentages of satisfaction (PS \%/I50) of fried Mullet steaks made from fresh and frozen stored samples

\begin{tabular}{|c|c|c|c|c|c|c|c|}
\hline \multirow{2}{*}{$\begin{array}{l}\text { Essential } \\
\text { Amino } \\
\text { Acid }\end{array}$} & \multirow{2}{*}{$\begin{array}{l}\text { USRDA } \\
\text { (1989 }\end{array}$} & \multicolumn{3}{|c|}{ Fried steaks from fresh sample } & \multicolumn{3}{|c|}{ Fried steaks from frozen stored sample } \\
\hline & & g/l00gsample & G.D.R (g) & P.S \%/150 g & g/l00g sample & G.D.R (g) & PS \%/I50 g \\
\hline Isoleucine & 0.819 & 0.975 & 84 & 179 & 0.905 & 90 & 165 \\
\hline Leucine & 1.971 & 1.58 & 125 & 120 & $\mathrm{I} .48$ & 133 & 112 \\
\hline Lysine & 1.008 & 1.39 & 73 & 207 & 1.28 & 79 & 190 \\
\hline Threonine & 0.567 & 0.891 & 64 & 235 & 0.824 & 69 & 217 \\
\hline Tryptophan & 0.315 & ND & ND & ND & ND & ND & ND \\
\hline Valine & 0.819 & 0.927 & 88 & 170 & 0.851 & 96 & 155 \\
\hline Histidine & 1.008 & 0.725 & 139 & 108 & 0.673 & 150 & 100 \\
\hline Meth+Cys & 1.071 & 0.665 & 161 & 93 & 0.606 & 177 & 84 \\
\hline Phenyl.+Tyr & 1.197 & 1.58 & 76 & 198 & 1.43 & 84 & 179 \\
\hline
\end{tabular}

Table 7 Daily requirements (GDR) and the percentages of satisfaction (PS \%/I50) of grilled Mullet steaks made from fresh and frozen stored samples

\begin{tabular}{|c|c|c|c|c|c|c|c|}
\hline \multirow{2}{*}{$\begin{array}{l}\text { Essential Amino } \\
\text { Acid }\end{array}$} & \multirow{2}{*}{$\begin{array}{l}\text { USRDA } \\
\text { (1989) }\end{array}$} & \multicolumn{3}{|c|}{ Grilled steaks from fresh sample } & \multicolumn{3}{|c|}{$\begin{array}{l}\text { Grilled steaks from frozen stored } \\
\text { sample }\end{array}$} \\
\hline & & $\begin{array}{l}\text { g/lo0g } \\
\text { sample }\end{array}$ & $\begin{array}{l}\text { G.D.R } \\
\text { (g) }\end{array}$ & P.S \%/l50 g & $\begin{array}{l}\mathrm{g} / 100 \mathrm{~g} \\
\text { sample }\end{array}$ & $\begin{array}{l}\text { G.D.R } \\
\text { (g) }\end{array}$ & PS \%/150 g \\
\hline Isoleucine & 0.819 & 0.981 & 83 & 180 & 0.937 & 87 & 171 \\
\hline Leucine & 1.971 & 1.66 & 119 & 126 & 1.55 & 127 & 117 \\
\hline Lysine & 1.008 & 1.41 & 71 & 210 & 1.3 & 78 & 193 \\
\hline Threonine & 0.567 & 0.947 & 60 & 251 & 0.85 & 67 & 224 \\
\hline Tryptophan & 0.315 & ND & ND & ND & ND & ND & ND \\
\hline Valine & 0.819 & 0.962 & 85 & 176 & 0.872 & 94 & 159 \\
\hline Histidine & 1.008 & 0.566 & 178 & 84 & 0.512 & 196 & 76 \\
\hline Meth +Cys & I.07I & 0.691 & 155 & 97 & 0.588 & 182 & 82 \\
\hline Phenyl. +Tyr & 1.197 & 1.75 & 68 & 219 & 1.6 & 75 & 200 \\
\hline
\end{tabular}


The results presented in Table 6 showed that Meth+Cys amino acids in the fried Mullet steaks made from fresh Mullet fish showed the highest GDR and the lowest PS/ $150 \%$ that were calculated by $161 \mathrm{~g}$ and $93 \%$, respectively. The same findings were also found for the fried sample made from Mullet steaks stored for 6.0 months. Data indicated that Meth+Cys amino acids showed the highest (GDR $177 \mathrm{~g}$ ) and lowest PS/150\% (84 \%). Based on these data it could be concluded that the consumption of $150 \mathrm{~g}$ of fried Mullet steaks made from fresh or frozen stored Mullet fish steaks covered more than the daily requirements of all the essential amino acid except for Meth + Cys that covered about $84-93$ and $\%$ of their daily requirements.

The results presented in Table 7 showed that histidine amino acid in the grilled Mullet steaks made from fresh Mullet fish showed the highest GDR and the lowest PS/150\% which were calculated by $178 \mathrm{~g}$ and $84 \%$, respectively. Also, the grilled sample made from Mullet steaks stored 6.0 months at $-18^{\circ} \mathrm{C}$ showed the same trend. Data indicated that histidine amino acid showed the highest GDR (196g) and lowest PS $/ 150 \%$ (76\%). Based on these data, the consumption of $150 \mathrm{~g}$ of grilled Mullet steaks covered more than the daily requirements of all the essential amino acids except for Meth+Cys and histidine which covered $97 \%$ and $84 \%$, respectively for grilled sample made from fresh Mullet fish and $76 \%$ and $82 \%$, respectively for the grilled sample made from frozen stored Mullet fish.

\section{Acknowledgements}

The study was supported by Fish Processing and Technology NIOF.

\section{Conflict of interest}

The authors have no competing interests.

\section{References}

1. Itthagarun A, King NM. Ectodermal dysplasia: a review and case report. Quintessence Int. 1997;28;595-602.

2. Bianca Zeponi Fernandes Mello, Thiago Cruvinel Silva, Daniela Rios, et al. Mini-implants: Alternative for Oral Rehabilitation of a Child with Ectodermal Dysplasia. Brazilian Dental Journal. 2015;26(1):75-78.

3. Pigno MA, Blackman RB, Cronin RJ, et al. Prosthodontic management of ectodermal dysplasia: A review of literature. J Prosthet Dent. 1996;76(5):541-545.
4. Calixto Fraiz F, Gugish R, Lopes Cavalcante B, et al. Hypohydrotic ectodermal dysplasia : a clinical case with longitudinal approach. The journal of contemporary dental practice. 2014;15(6):788-791.

5. Yumiko Nakayama, Yoshiyuki Baba, Michiko Tsuji, et al. Dentomaxillofacial characteristics of ectodermal dysplasia, Japanese Teratology Society. Congenital Anomalies. 2015;55:42-48.

6. Bal C, Bal BT, Tüfekçioğlu D. Treatment Considerations for a Patient with Hypohidrotic Ectodermal Dysplasia: A Case Report. J Contemp Dent Pract. 2008;9(3):128-34.

7. Elia Sfeir, Mona G Nahass, Ayman Mourad. Evaluation of Masticatory Stimulation Effect on the Maxillary Transversal Growth in Ectodermal Dysplasia Children, International Journal of Clinical Pediatric Dentistry. 2017;10(1):55-61.

8. Bidra AS, Martin JW, Feldman E. Complete denture prosthodontics in children with ectodermal dysplasia: review of principles and techniques. Compend Contin Educ Dent. 2010;31(6):426-433.

9. Solfrid Sørgjerd Saltnesa, Janicke Liaaen Jensena, Saeves R, et al. Associations between ectodermal dysplasia, psychological distress and quality of life in a group of adults with oligodontia. Acta Odontol Scand. 2017;75(8):564-572.

10. Bajraktarova Valjakova E, Misevska C, Korunoska Stevkovska V, et al. Prosthodontic management of hypohidrotic ectodermal dysplasia: a case report. South Eur J Orthod Dentofac Res. 2015;2(2):20-26.

11. Pipa-Vallejo A, López-Arranz-Monje E, González-García M, et al. Treatment with removable prosthesis in hypohidrotic ectodermal , dysplasia. A clinical case. Med Oral Patol Oral Cir Bucal. 2008;1;13(2):E119-E123.

12. Montanari M, Callea M, Battelli F, et al. Oral rehabilitation of children with ectodermal dysplasia. BMJ Case Rep. 2012.

13. Maiorana C, Poli PP, Poggio C. Oral rehabilitation of a patient with ectodermal dysplasia treated with fresh frozen bone allografts and computer-guided implant placement: a clinical case report. J Oral Maxillofac Surg. 2017;75(5):939-954.

14. Bergendal B, Ekman A, Nilsson P. Implant failure in young children with ectodermal dysplasia: A retrospective evaluation of use and outcome of dental implant treatment in children in Sweden. Int J Oral Maxillofac Implants. 2008;23(3):520-524.

15. Somayeh Hekmatfar, Karim Jafari, Raziyeh Meshki, et al. Dental Management of Ectodermal Dysplasia: Two Clinical Case Reports. $J$ Dent Res Dent Clin Dent Prospects. 2012;6(3):108-112. 